Volume 2, Issue 1, pages 35-44

p-ISSN 2655-8564, e-ISSN 2685-9432

\title{
A Study of Statics on Driyarkara Electric Automobile Chassis Prototype
}

\author{
A. H. Astyanto ${ }^{1, *}$, Y. R. Yanto ${ }^{1}$, A. B. W. Adi $^{1}$ \\ ${ }^{1}$ Department of Mechanical Engineering, Sanata Dharma University, \\ Yogyakarta, Indonesia \\ *Corresponding Author: achil.herma@usd.ac.id
}

(Received 12-06-2019; Revised 03-02-2020; Accepted 03-02-2020)

\begin{abstract}
A design phase commonly initiates either a product invention or development. Before it continues to the fabrication steps, a modern computational, enabling a simulation study during the phase, often gives opportunity to develop its effectiveness and efficiency. Through several boundary conditions, some analytical and/or computational approaches could be determined. This paper aims to elaborate both static simulations and simple experimental tests on an electric automobile chassis prototype. An application based on finite element analysis was assessed to carry out both von Misses stresses and the nodal displacements regarding the construction and/or material strength to a static loads mode. Furthermore, an experimental based examination was also executed as a simple physical validation. The studies emphasize accepted results on von Misses stresses and nodal displacements for both simulation and experimental approaches.
\end{abstract}

Keywords: chassis statics, von misses stresses, nodal displacements, finite element. 


\section{International Journal of Applied Sciences and Smart Technologies}

Volume 2, Issue 1, pages 35-44

p-ISSN 2655-8564, e-ISSN 2685-9432

\section{Introduction}

Electric technologies inside automobiles have become worldwide during this decade. According to several studies, it offers more benefits than the conventional technologies. Mainly, electric technologies are claimed more efficient on the fuel consumption. Some others agree that the technologies are also eco-friendly on the environmental perspectives. People are now taking more concern to develop electric technologies inside automobiles which do not pollute the fresh air, and can also minimize the sound noisy.

In accordance with those several studies related electric technologies positive aspects, Indonesian government through a particular regulation lauched the National Energy Resources General Plan, called RUEN in 2017 [1]. In the regulation mentioned, sustain developments on electric automobile technologies are fully supported by the government. Some incentive packages are provided by the government for both industrial sectors and educational institutions who develop the technologies consistenly [2].

Both automobile industries and higher educational institutions welcome warmly the government offering. Through several annual exhibitions such as Gaikindo Indonesia International Motor Show (GIIAS), and Indonesia International Motor Show (IIMS), some leaders in automobile industries and also higher educational institutions have offered their performances regarding electric automobile technologies through some prototypes [3, 4].

A prototype design commonly initiates product developments, including technologies in automobiles. Nowadays, parametric based on computing aided design (CAD) features inside the technologies has improved its ease and efficiency in doing engineering design projects. Furthermore, it also enables users delivering simulation studies, including statics during design phases which is available on computing aided engineering (CAE) packages. The solution commonly involves a finite element analysis based computational methodology $[5,6]$. 


\section{International Journal of Applied Sciences and Smart Technologies}

Volume 2, Issue 1, pages 35-44

p-ISSN 2655-8564, e-ISSN 2685-9432

On a static analysis, it is also usual to conduct an experimental test through physical tests as either a comparison or validation towards the analytical/simulation results. It sometimes deals with finding the material element stresses working in the construction, namely von Misses stresses, and also the nodal displacements. Through the tests, deviations or comparisons between simulation results and physical tests can be determined. However, it can be assessed as a validation to the simulation studies [7, 8].

In this study, statics simulations based on a finite element analysis application and basic experimental tests are elaborated. The results involve von Misses stresses and nodal displacements comparison between the simulation and the experimental tests.

\section{Research Methodology}

Figure 1 shows the flowchart of this research. Several chassis designs by a CAD application initiated the research milestones. Some optional designs were taking into considerations during the phase. It remained models with various possibilities geometries in which the construction should able to support 0.7 kilo newton $(k N)$ of a minimum static load. Furthermore, a simple design was chosen based on the model simulation results. The optimum chassis design and the manufactured chassis built is shown by Figure 2.

Model simulations were conducted by a finite element analysis based application. It deals with forces acting on the construction as compensations of the real plan approaches conditions. Furthermore, results analysis involved calculations on principal stresses i.e. the maximum and minimum stresses, transformasion of plane stresses, von Misses stresses, nodal displacements and factor of safety [9].

The following step was materials preparation. Material applied in this studies is $20 \mathrm{~mm} \times 15 \mathrm{~mm} \times 1.5 \mathrm{~mm} \mathrm{Al} 1060-H 16$ square-hollow for both the simulation and fabrication. It also dealt with some requirements regarding the maximum weight limitation of the automobile's construction. The material properties, including Young modulus, material density, the poisson ration and the yield strength of Al $1060-$ $H 16$ are shown in Table 1. 


\section{International Journal of Applied Sciences and Smart Technologies}

Volume 2, Issue 1, pages 35-44

p-ISSN 2655-8564, e-ISSN 2685-9432

Table 1. Material properties

\begin{tabular}{ccccc}
\hline Material & $\begin{array}{c}\text { Elastic } \\
\text { Modulus, MPa }\end{array}$ & $\begin{array}{c}\text { Mass } \\
\text { Density, } \\
\mathrm{kg} / \mathrm{m} 3\end{array}$ & $\begin{array}{c}\text { Poisson's } \\
\text { Ratio }\end{array}$ & $\begin{array}{c}\text { Yield Strength, } \\
\text { MPa }\end{array}$ \\
\hline Al $1060-H 16$ & 69 & 2705 & 0.33 & 105 \\
\hline
\end{tabular}

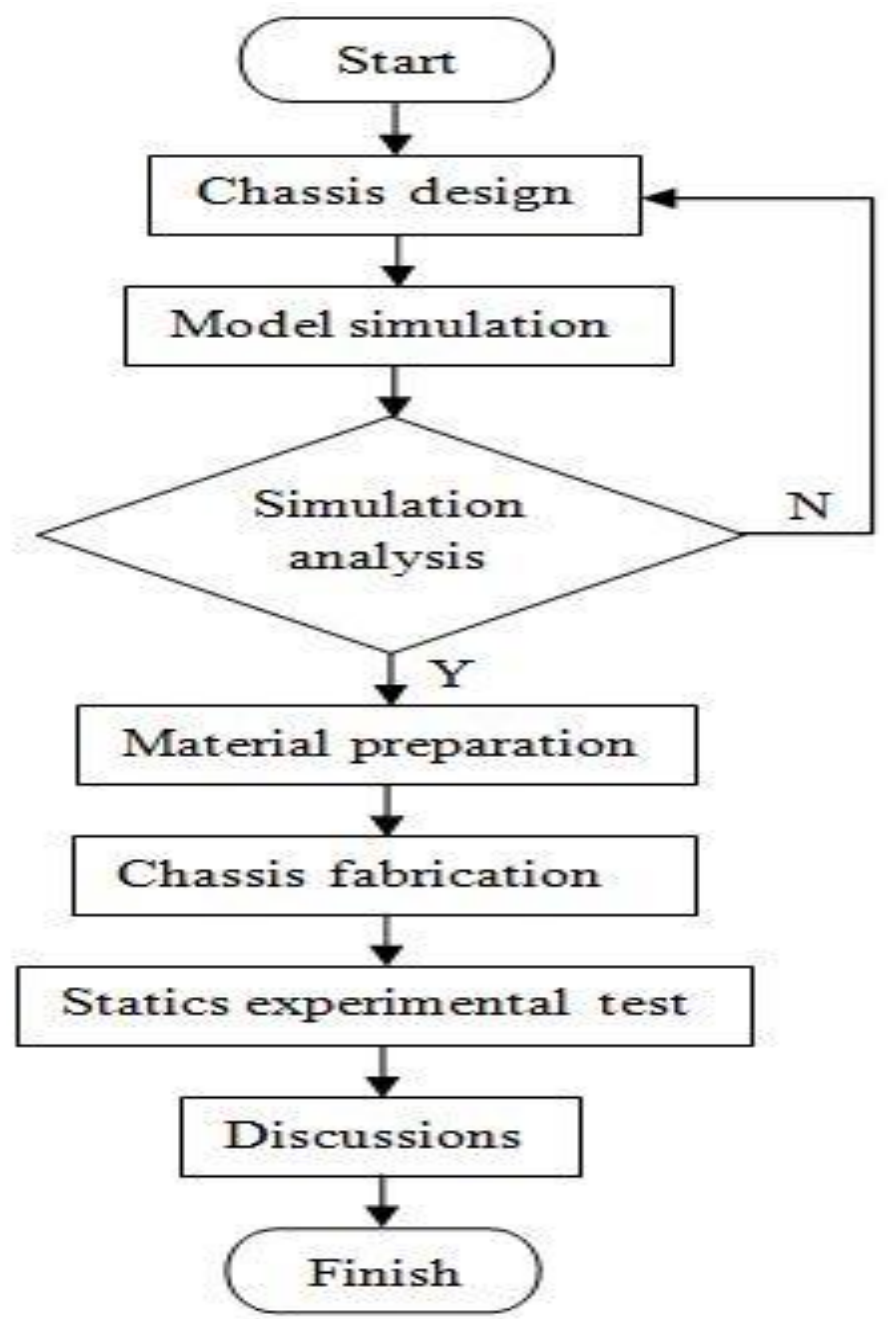

Figure 1. Flowchart of research

The chassis fabrication involved some processes of production, i.e. metal cutting and joining. It covered the processes to manufacture the geometrical shape of the chassis prototype design elected. Since the material proposed was the Aluminum, then 


\section{International Journal of Applied Sciences and Smart Technologies}

Volume 2, Issue 1, pages 35-44

p-ISSN 2655-8564, e-ISSN 2685-9432

(solid metal arc welding) SMAW was applied. The global size of the chassis is $2 m \times$ $0.5 m \times 0.5 m$ in length, width and heigth respectively.

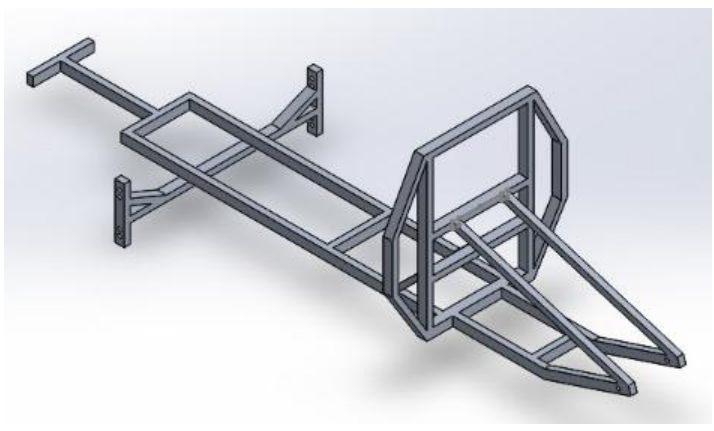

(a)

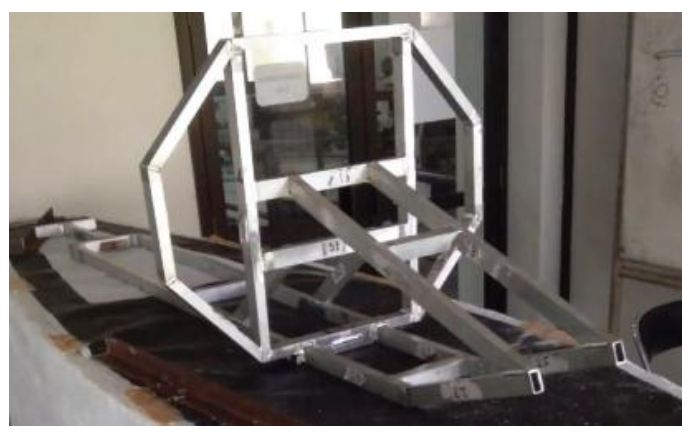

(b)

Figure 2. (a) Chassis prototype design and (b) after fabricated construction

Statics simulation usually requires a comparison as a physical validation. In a construction phase of developing an automobile chassis, it deals with a particular mechanics of materials approach namely forces acting in a solid body. However, the forces acting and particular strength of the construction should be determined in accordance with the properties of material strength such as the yield and ultimate strenghts. We can see on Figure 3.

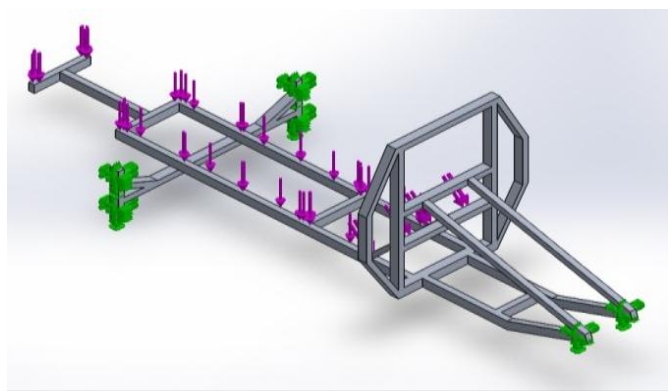

(a)

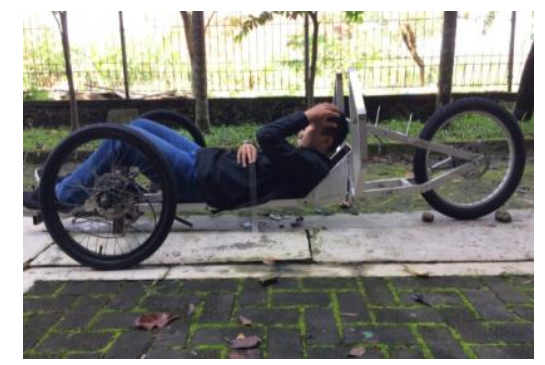

(b)

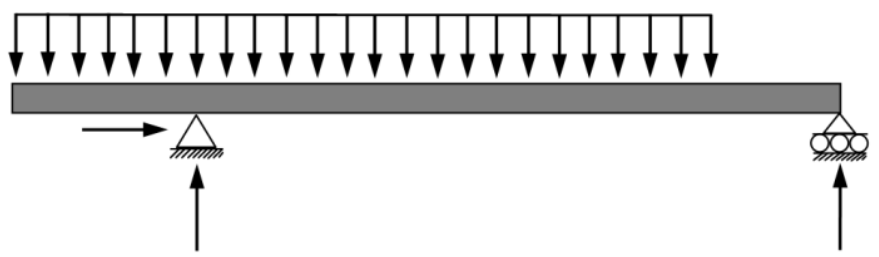

Figure 3. (a) Simulation boundary conditions, (b) Actual loading condition, and (c) Analytical calculation approach 


\section{International Journal of Applied Sciences and Smart Technologies}

Volume 2, Issue 1, pages 35-44

p-ISSN 2655-8564, e-ISSN 2685-9432

A chassis in automobiles is a particular construction frame in which the loads of all components including the driver or passanger's weight are received and distributed. The Newton first law, involving forces acting on a solid body, states that the forces resultant of a moving body increases linearly with the acceleration, and formulated as:

$$
\sum F=m a
$$

Meanwhile, a normal stress, defined as normal force per unit area, is formulated as:

$$
\sigma_{x, y}=\frac{F_{n}}{A}
$$

Principal stresses, which consists of maximum and minimum stresses, are derived by transforming applied stresses as plane stresses and formulated as:

$$
\sigma_{\text {max.min }}=\frac{\sigma_{x}+\sigma_{y}}{2} \pm \sqrt{\left(\frac{\sigma_{x}+\sigma_{y}}{2}\right)^{2}+\tau_{x y}^{2}}
$$

The safety factor emphasizes the ratio between material yield strength to applied stresses and formulated as:

$$
F S=\frac{\sigma_{y}}{\sqrt{\sigma_{a}^{2}-\sigma_{a} \sigma_{b}-\sigma_{b}^{2}}}
$$

Here are in the equations:

$F_{n} \quad: \quad$ is the normal force acting on the body

$\sigma_{Y} \quad:$ is the material yield strength

$\sigma_{b}$ and $\quad:$ are the applied principal stresses

$\sigma_{a}$

$\tau_{x y} \quad:$ is the plane shear stress.

\section{Results and Discussions}

Figure 4 describes load vectors, von Misses stresses, and analytical space diagram as an approach to the factual condition. On the other hand, Figure 5 shows the nodal displacements on the chassis as a result of several applied load magnitudes. It deals with the boundary conditions applied as an approach on the simulation analysis. The red color indicates nodals/places with the higher impact. From the simulation results, it shows that the maximum von Misses stress on the chassis reaches up to a magnitude of 


\section{International Journal of Applied Sciences and Smart Technologies}

Volume 2, Issue 1, pages 35-44

p-ISSN 2655-8564, e-ISSN 2685-9432

$16 \mathrm{MPa}$ by applying the required load $0.76 \mathrm{kN}$ of force. Meanwhile, the maximum nodal displacement on that required load reaches up to $1.42 \mathrm{~mm}$ by applying the equivalent force.
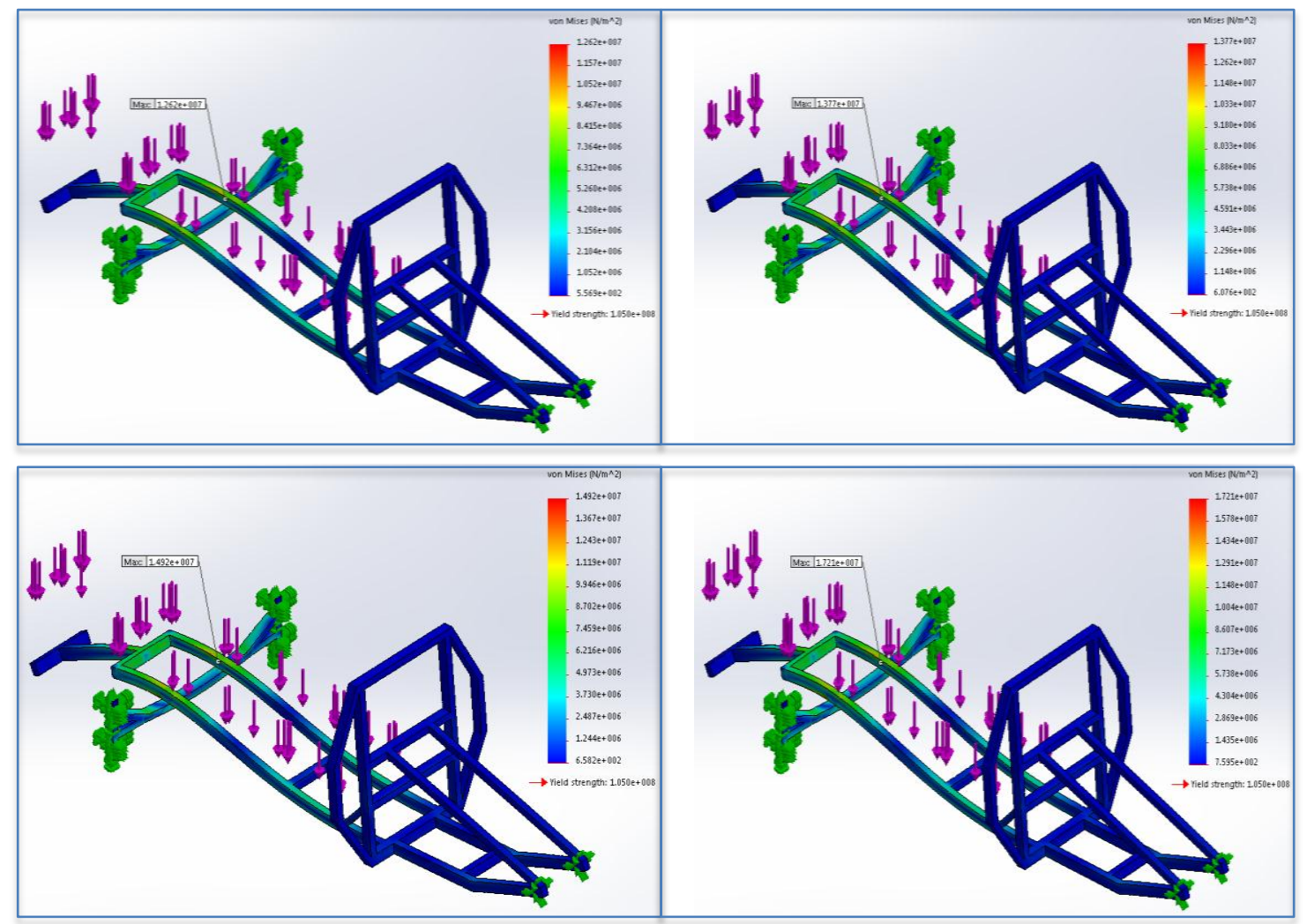

Figure 4. Von Misses Stresses distribution acting on the chassis

It is usual to reach an identification of deformation through visual observation on the chassis conditions [8]. Table 2 describes load simulation and experimental results on the maximum nodal displacements in accordance with some visual observations during several loading conditions of the chassis. On applied loads $0.50,0.6$ and $0.76 \mathrm{kN}$ of forces, respectively, it shows that there are acceptable criterion between the simulation and experimental results. 


\section{International Journal of Applied Sciences and Smart Technologies}

Volume 2, Issue 1, pages 35-44

p-ISSN 2655-8564, e-ISSN 2685-9432
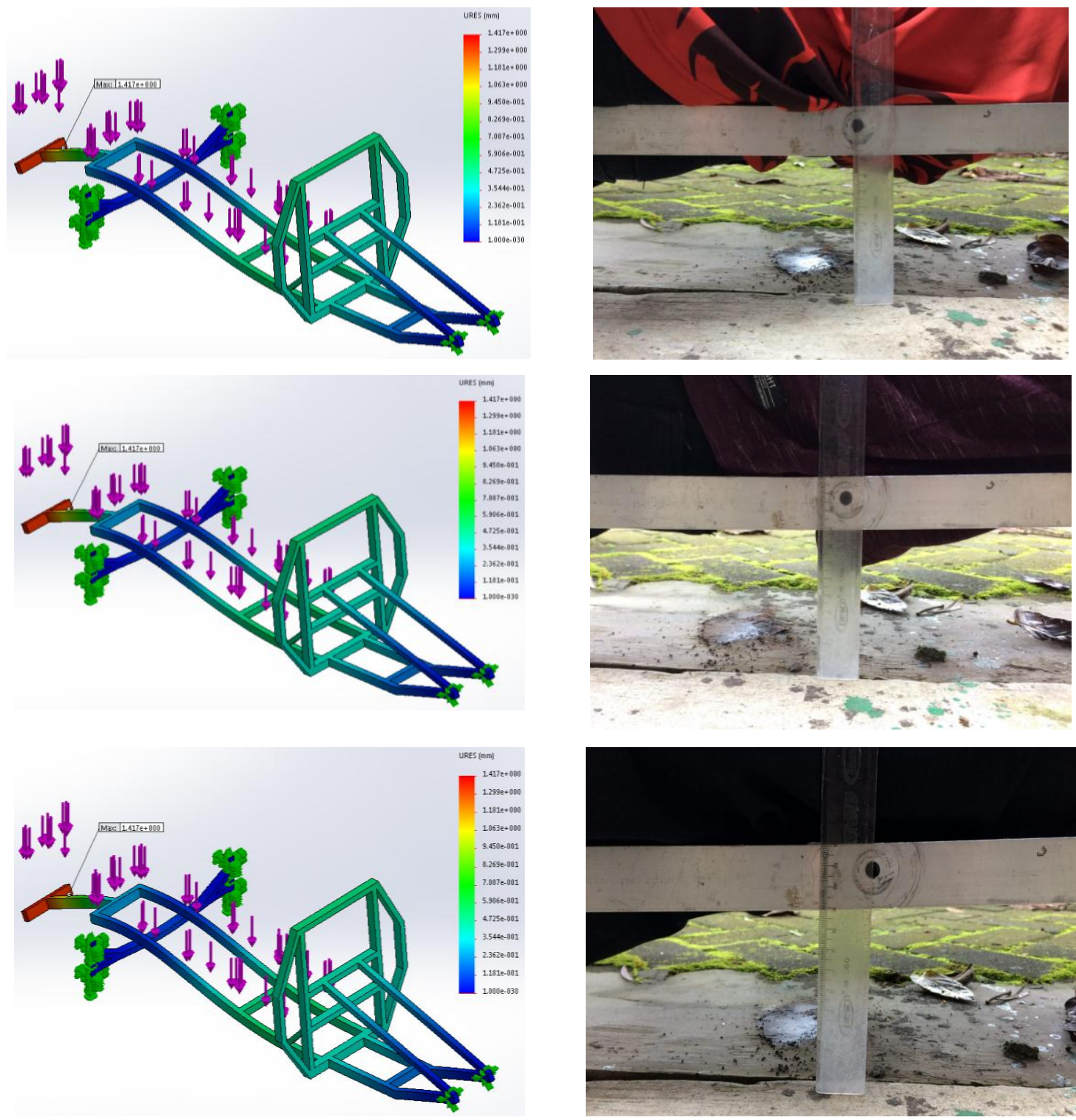

Figure 5. Nodal displacements distribution on the chassis

Table 2. Experimental visual observation

\begin{tabular}{cccccc}
\hline \multicolumn{2}{c}{ Applied load } & \multicolumn{4}{c}{ Experimental visual observation } \\
\hline $\mathrm{kg}$ & $\mathrm{kN}$ & Bending & Cracking & Fracture & Deformation \\
50 & 0.50 & No & No & No & No \\
57 & 0.57 & No & No & No & No \\
79.5 & 0.79 & No & No & No & No \\
\hline
\end{tabular}




\section{International Journal of Applied Sciences and Smart Technologies}

Volume 2, Issue 1, pages 35-44

p-ISSN 2655-8564, e-ISSN 2685-9432

\section{Conclusions}

Statics studies of an electric automobile chassis prototype have been presented on this paper. The results emphasize accepted deviations between simulation and experimental studies. On the required applied load of $0.76 \mathrm{kN}$ force, simulation studies show that the maximum von Misses stress and nodal displacement reach up to 0.48 MPa and $2.5 \mathrm{~mm}$, respectively. These results describe that the material used, i.e. Al $1060-H 16$ with $105 \mathrm{MPa}$ of yield strength, for the construction is on the acceptable criteria. On the other hand, the experimental tests show that applying loads do not deform the chassis construction. However, optimization studies are still pursued as further developments in accordance with both the chassis design shapes/geometries and material selection. Furthermore, dynamic and lateral loads are proposed to be calculated particularly on the chassis design.

\section{Acknowledgements}

The authors would like to acknowledge the Institution of Research and Community Service (LPPM) Sanata Dharma University for the funding of these studies.

\section{References}

[1] https://www.cnbcindonesia.com/news/20180224120933-4-5336/dukung-penuhmobil-listrik-sri-mulyani-siapkan-insentif (Accessed on 19-02-2018).

[2] https://www.cnbcindonesia.com/news/20180224120933-4-5336/menanti-insentifmobil-listrik-di-tanah-air (Accessed on 24-02-2018).

[3] https://otomotif.kompas.com/read/2018/04/03/182200315/festival-mobil-listrikakan-meriahkan-iims-2018 (Accessed on 11-03-2019).

[4] https://www.oto.com/berita-mobil/giias-2018-5-mobil-listrik-hadirkan-ragamteknologi-terdepan-21181938 (Accessed on 11-03-2019).

[5] Z. Abadi, Fauzun, and M. Mahardika, "Analisa tegangan pada desain frame automatic guided vehicles (AGV) dengan pembebanan statis menggunakan 


\section{International Journal of Applied Sciences and Smart Technologies}

Volume 2, Issue 1, pages 35-44

p-ISSN 2655-8564, e-ISSN 2685-9432

software abaqus 6.11," Proceeding Seminar Nasional Teknik Mesin ke-9 (SNTM 9), D51-D54, Agustus 2014.

[6] J. S. Pribadi, Fauzun, and M. Mahardika, "Analisa komponen kristis pada desain automatic guided vehicles (AGV) Subsystem lifting dengan pembebanan statis menggunakan software abaqus 6.11," Proceeding Seminar Nasional Teknik Mesin ke-9 (SNTM 9), D15-D20, Agustus 2014.

[7] M. Yamin, D. Satyadarma, and O. A. Hasanudin, "Analisis tegangan pada rangka mobil boogie," Proceeding Seminar Ilmiah Nasional Komputer dan Sistem Intelijen (KOMMIT), 49-56, Agustus 2018.

[8] N. Wahyudi and Y. A. Fahrudi, "Studi eksperimen rancang bangun rangka jenis ladder frame pada kendaraan sport," Journal of Electrical Electronic Control and Automotive Engineering, 1 (1), 71-74, 2016.

[9] F. P. Beer, E. R. Johnston, J. T. DeWolf, and D. F. Mazurek, Mechanics of Materials, Sixth Ed, McGraw-Hill Publishing Company, New York, USA, 2012. 